\title{
JOURNAL OF UOEH
}

\section{（産業医科大学杂倠誌）}

\author{
VOLUME 39 \\ pp $1-324$
}

$\begin{array}{llll}2 & 0 & 1 & 7\end{array}$

Published by

The University of Occupational and Environmental Health, Japan.

1-1 Iseigaoka, Yahatanishi-ku, Kitakyushu 807-8555, Japan

(産 業 医 科大学) 



\section{JOURNAL OF UOEH}

\section{Contents of Volume 39}

\section{Number 1, March 1, 2017}

Tadashi Arao, Yosuke Okada, Keiichi Torimoto, Kei Sugai, Takashi Otsuka, Akira Kurozumi and Yoshiya TANAKA

Comparison Between Effectiveness of $100 \mathrm{mg}$ /day Sitagliptin and a Switch to Mitiglinide Calcium Hydrate/Voglibose from $50 \mathrm{mg} /$ day Sitagliptin in Patients with Type 2 Diabetes

Kuninobu Kashiyama, Shinjo Sonoda and Yutaka Otsuji

Reconsideration of Secondary Risk Management Strategies in Patients with Ischemic Heart Disease

Toshiyuki UMATA

Estimation of Biological Effects of Tritium

(in Japanese) $\cdots \cdots \cdots \ldots \ldots \ldots . \cdots \cdot 25-33$

Nobuhisa OCHIAI and Hiroyuki Kondo

Color Functionality Used in Visual Display for Occupational and Environmental Safety and

Managing Color Vision Deficiency

(in Japanese)

$35-45$

Hayato NAKAmura, Toyohi Isse and Akinori SAKAI

Changes of Working Responsibilities and Intentions of Industrial Physicians (Graduates of University

of Occupational and Environmental Health, Japan) in a Comparison Between 2001, 2008 and 2015

Questionnaire Analyses

(in Japanese)

$47-54$

Tomoko Shiraishi, Hiroshi Ishimoto, Kentaro Akata, Toshinori Kawanami, Kazuhiro Yatera and

Hiroshi MukaE

An Autopsy Case Report of Adult T-cell Leukemia Accompanied by Rheumatoid Arthritis Mimicking

Diffuse Panbronchiolitis

(in Japanese)

$.55-61$

Keiko Tsuji, Naomi Iwata, Hiromi Kodama, Tomoko Hagiwara, Kiyoko TaKai and Maki Matsumoto

Development of Teaching Materials in Basic Nursing Using Virtual Reality

- Ceiling Image Teaching Materials of a Hospital Room -

(in Japanese)

$63-68$

Akira Nakazawa, Ning Tang, Yoshinori Inoue, Waka Kamichatani, Toshifumi Katoh, Mitsuru Saito,

Kenji Obara, Akira Toriba and Kazuichi HaYakawa

Evaluation of Adsorption Characteristics of a Fibrous Adsorbent Containing Zwitter-Ionic Functional

Group, Targeting Organic Acids

(in Japanese)

$69-74$

Abstracts of the 34th Annual Meeting of the UOEH Association of Health Sciences (in Japanese)

$75-122$ 


\section{Number 2, June 1, 2017}

Yasuo Morimoto, Hiroto Izumi, Yukiko Yoshiura, Yuri FujISAwa and Katsuhide Fujita

Significance of Intratracheal Instillation Tests for the Screening of Pulmonary Toxicity of

Nanomaterials

Chinatsu Nishida, Kazuhiro Yatera, Takashi Kido, Shingo Noguchi, Kentaro Akata, Minako Hanaka,

Kei Yamasaki, Teppei Hoshino, Masayuki Shimono, Hiroshi Ishimoto, Noriho Sakamoto and Hiroshi Mukae

Two Cases of Tuberous Sclerosis Complex Suggestive of Complicating Multifocal Micronodular

Pneumocyte Hyperplasia: A Case Report

Riho Iwasaki, Azusa Arimoto, Takashi Naruse, Satoko Nagata and Sachiyo Murashima

The Importance of the Maternal/Self-Role Satisfaction for Reducing Anxiety: A Cross-Sectional Survey of Japanese Mothers

Hiroyuki ToyodA and Koji MorI

Conduct of Occupational Health During Major Disasters: A Comparison of Literature on Occupational Health Issues in the World Trade Center Terrorist Attack and the Fukushima Nuclear Power Plant Accident

(in Japanese) $153-159$

Takao Amaike, Toshihisa Tamura, Atsuhiro Koga, Kazunori Shibao, Aiichiro Higure and Keiji Hirata A Case of Retroperitoneal Paraganglioma

(in Japanese) $161-166$

Yuzuru Inoue, Fumi Joden, Kei Yabuki, Nagahiro Sato, Noritaka Minagawa, Takefumi Katsuki, Norihiro Sato, Takahisa Nagata, Kazunori Shibao, Atsuji Matsuyama, Takatoshi Aoki and Keiji HiRata A Case of Matrix-Producing Carcinoma of the Breast

(in Japanese) $167-173$

Keiko Tsuji, Naomi Iwata, Hiromi Kodama, Tomoko Hagiwara, Kiyako TaKai, Yoko Sasaki, Yoshie Nagata and Maki Matsumoto

Nursing Education Trial Using a Virtual Nightingale Ward

(in Japanese) $175-179$

Mitsuo Hinoue and Hajime HorI

Examination of a New Desorption Method for Solid Adsorption Method of Working Environment Measurement -Attempt to Improve Desorption Efficiency of Organic Solvents from a CoconutShell-Activated Carbon Using Surfactant Solutions ${ }^{-}$

(in Japanese) $181-185$

\section{Number 3, September 1, 2017}

Toshihiko Myojo, Tomohisa Nagata and Jos VerbeeK

The Effectiveness of Specific Risk Mitigation Techniques Used in the Production and Handling of Manufactured Nanomaterials: A Systematic Review $187-199$ 
Kanae BeKki, Yohei InABA, Shigehisa UchiYAma and Naoki Kunugita

Comparison of Chemicals in Mainstream Smoke in Heat-not- burn Tobacco and Combustion Cigarettes

Yasuo Chojin, Hiroshi Ishimoto, Shingo Noguchi, Toshinori Kawanami, Tatsuji Kato, Hiroshi Mukae and Kazuhiro YATERA

Frequent Oxygen Desaturation During Sleep on the Day of Bronchoscopy Evaluated by Continuous Pulse Oximeter Monitoring

Mitsuhiro Ochi, Hiroshi OHashi, Kenji Hachisuka and Satoru SaEKI

The Reliability and Validity of the Japanese Version of the Stroke Impact Scale Version 3.0

$$
\text { (in Japanese) }
$$

Nobutaka Matayoshi, Norihiro Sato, Takashi Okimoto, Takehide Tajima, Koichi Arase, Nagahiro Sato,

Toshihisa Tamura, Kazunori Shibao, Aiichiro Higure and Keiji Hirata

A Review of 7 Cases of Laparoscopic Cholecystectomy for Pediatric Cholecystolithiasis

(in Japanese) $\cdot 223-227$

Hironori Yada, Mako KobaYashi, Ryo Odachi and Toshie Yamane

Factors Relating to Self-Efficacy Among Psychiatric Nurses

(in Japanese)

$\cdot .229-234$

Shunsuke Araki, Tomoko Saito, Saori Ichikawa, Kaori Saito, Tsuzumi TaKada, Satoko Noguchi,

Miki Yamada and Fumi NaKagawa

Family-Centered Care in Neonatal Intensive Care Units: Combining Intensive Care and Family Support

(in Japanese) $\cdots \cdots \cdots \cdots \cdot \cdots \cdot 235-240$

Tadashi Arao, Yosuke Okada, Fumi Uemura, Shigeru Nishizawa and Yoshiya Tanaka

A Case of Acromegaly in which a Pituitary Gland Tumor was Reduced Significantly by Administering

Octreotide Long Acting Release (LAR) and Could Be Removed Surgically $\quad$ (in Japanese)

$241-245$

Announcement of the 35th Annual Meeting of the UOEH Association of Health Sciences and the 29th National Conference of the Research Association for the Promotion of Occupational Medicine

(in Japanese) $247-248$

\section{Number 4, December 1, 2017}

Yong Heo, Sang-Hoon KIM, Seok-Ki LeE and Hyoung-Ah KIM

Factors Contributing to the Self-Reported Prevalence of Multiple Chemical Sensitivity in Public

Facility Workers and the General Population of Korea

Yasushi Kudo, Keiko Kono, Ryuko Kume, Ayako Matsuhashi and Akizumi Tsutsumi

Feelings about Nursing Assistants that Enhance the Work Motivation of Japanese Registered Nurses

and Licensed Practical Nurses

$259-269$ 
Ken Otsuji, Satoko Simizu, Takeru Endo, Ayako Kanazawa, Hideaki Arai, Keiji Nagata, Nobuya Harayama, Shunichi NiheI, Keiji Aibara, Mitsumasa SAIto and Masayuki Kamochi

A Case of Infectious Enterocolitis with Hyperammonemia $\cdot 271-276$

Ryuji OKazaki, Kazuhiro OHga, Makoto Yoко-o and Masaoki KoHzaKi

A Survey about the Radiation Effects and A Health Survey of Fukushima Inhabitants after the Fukushima Daiichi Nuclear Power Plant Accident (in Japanese) $\cdot 277-290$

Yoshinobu Ichiki, Takashi Iwanami, Kesei Kakizoe, Takayuki Hamatsu, Taketoshi SueHIro, Kazue Yoneda, Fumihiro Tanaka and Keizo Sugimachi Analysis of Advanced or Postoperative Recurrent Non-small Lung Cancer Cases Treated with Nivolumab (in Japanese) $291-297$

Hiromi Kodama, Chiemi Ishida and Fumiko Yasukata

The Role of Mid-Career Nurses in Educating New Nurses: from the Perspective of Self-Efficacy

(in Japanese) $299-308$

Teruo Iwata, Yuusuke NABE, Takeshi HanagiRI and Fumihiro TANAKA

A Successful Case of Tracheal Segmental Resection and Reconstruction for Cicatricial Tracheal Stenosis (in Japanese) $309-312$

Journal of UOEH, List of Referees for Volume 39 (No.1-4)

(in Japanese) 313

Journal of UOEH, Contents of Volume 39 (No.1-4)

(in Japanese) $315-324$ 
産業医科大学雑誌 第 39 巻 $\quad(1-4$ 号 $)$

総目次

第 1 号 2017年 3 月 1 日

新生 忠司 岡田 洋右 鳥本 桂一 須貝 慧 大塚 隆史 黒住 旭 田中 良哉 2型糖尿病患者におけるシタグリプチン $50 \mathrm{mg}$ から $100 \mathrm{mg}$ への増量とミチグリニド カルシウム水和物・ボグリボースへの切り替えにおける有用性に関する比較検討

(英文) $1-9$

樫山 国宣園田 信成尾辻豊

虚血性心疾患の 2 次予防を再考する $11-24$

馬田 敏幸

トリチウムの生体影響評価 $25-33$

落合 信寿近藤 寛之

産業・環境安全のための視覚表示に用いる色彩の機能性と色覚異常への対応 $35-45$

中村早人 一瀬 豊日 酒井 昭典

産業医科大学卒業生産業医の産業医業務に対する意識の推移

-2001 年, 2008 年, 2015 年調査の比較一

$47-54$

白石 朝子 石本 裕士 赤田憲太朗川波 敏則 矢寺和博迎寛

関節リウマチを合併し,びまん性沉細気管支炎類似の病像を呈した成人下細胞性白血病の

1 剖検例

$55-61$

辻慶子 岩田 直美 児玉 裕美 萩原 智子 鷹居 樹八子 松本 真希 仮想病棟を用いた病室の天井画像教材の開発

中澤 章 唐 寧 井上 嘉則 上茶谷若 加藤敏文 齋藤 満 小原健嗣

鳥羽陽早川 和一

両性イオン型繊維状吸着材の有機酸に対する吸着特性評価

$69-74$ 


\section{第 2 号 2017 年 6 月 1 日}

森本 泰夫 和泉 弘人 吉浦 由貴子 藤澤 有里 藤田 克英

気管内注入試験は, 工業用ナノ材料の肺有害性スクリーニングとして有用である

(英文)

$123-132$

西田 千夏 矢寺 和博 城戸 貴志 野口 真吾 赤田 憲太朗 花香 未奈子 山㠃 啓

星野 鉄兵下野 昌幸石本 裕士 坂本憲穂迎寛

結節性硬化症に伴う多巣性微小結節性肺細胞過形成を呈したと考えられる2症例

(英文)

$133-141$

岩㟝りほ 有本梓成瀬昂永田智子村嶋 幸代

母親役割/母親以外の自己の役割に満足することの重要性 : 子育て中の母親の不安軽減の

ためにー母親への横断調査よりー

(英文)

$143-151$

豊田裕之森晃爾

大災害における産業保健の課題 : 世界貿易センタービルテロ事件と福島第一原子力発電所

事故における産業保健上の課題に関する文献の比較による考察

$153-159$

天池 孝夫 田村 利尚 古賀 敦大 柴尾 和徳 日暮 愛一郎 平田 敬治

後腹膜傍神経節腫の 1 例

$161-166$

井上 譲 城田 ふみ矢吹 慶 佐藤 永洋皆川紀剛 勝木 健文 佐藤典宏

永田貴久 柴尾和德松山篤二 青木 隆敏平田敬治

乳腺基質産生癌 (matrix-producing carcinoma)の 1 例

$167-173$

辻 慶子 岩田 直美 児玉 裕美 萩原 智子 鷹居 樹八子 笹木 葉子 長多 好恵

松本 真希

仮想ナイチンゲール病棟を用いた看護教育の試み

$175-179$

樋上 光雄 保利一

作業環境測定における個体捕集法の新たな脱着法の検討－界面活性剂溶液によるヤシ殼活性

炭からの有機溶剂の脱着率向上の試み-

$181-185$

\section{第 3 号 2017 年 9 月 1 日}

明星 敏彦永田 智久 ジョス バビーク

工業用ナノマテリアルの製造と取扱いで用いられる個別のリスク低減対策の効果：

システマティックレビュー

(英文)

$187-199$ 
戸次 加奈江 稲葉 洋平 内山茂久 欅田 尚樹

加熱式夕バコと燃焼式タバコの主流煙中に含まれる有害成分の比較

(英文)

$201-207$

長神 康雄 石本 裕士 野口 真吾川波 敏則 加藤 達治迎 寛 矢寺 和博 連続酸素飽和度モリタリングを用いた気管支鏡検査当日の睡眠時における酸素飽和度低下の 検証

越智 光宏 大橋 浩 蜂須賀 研二 佐伯 覚 Stroke Impact Scale version 3.0の日本語版の作成および信頼性と妥当性の検討 $215-221$

又吉 信貴 佐藤 典宏 沖本 隆司田嶋 健秀荒瀬光一佐藤 永洋田村利尚 柴尾 和徳 日暮 愛一郎 平田 敬治 小児胆囊結石症に対する腹腔鏡下胆囊摘出術 7 例の検討

矢田 浩紀 小林 眞子 大達 亮 山根 俊恵 精神科看護師の自己効力感に関連する要因

荒木 俊介 斉藤 朋子市川さおり斉藤香織高田鼓野口聡子 山田美貴 中川ふみ 新生児集中治療における Family-Centered Careの重要性 〜集中治療と育児支援との両立を 目指した取り組み〜

新生 忠司岡田 洋右 上村芙美西澤 茂 田中 良哉 オクトレオチドLong Acting Release (LAR) 投与により下垂体腫瘍が著明に縮小し治癒切除し

得た先端巨大症の 1 例 $241-245$

第35 回産業医科大学学会総会および第29回産業医学推進研究会全国大会 $247-248$

\section{第 4 号 2017年12月 1 日}

ホー ヨン キム サンフン イ スッキ キム ヒョンア 韓国の公共施設の勤労者と一般人の多種化学物質過敏症の自己申告有症率に関係する要因

工藤 安史河野 啓子 久米龍子松橋 綾子堤明純 わが国の看護師および准看護師における看護補助者のおかげで勤労意欲が高まるという意識 
尾辻 健 清水 智子 遠藤 武尊 金澤 綾子 荒井秀明 長田圭司 原山 信也

二瓶 俊一 相原 啓二 齋藤 光正蒲地 正幸

高アンモニア血症を伴った感染性腸炎の 1 例

岡嵉 龍史 太神和廣 横尾誠香﨑 正宙

福島県における原発事故後の放射線影響と福島県民健康調査に対する意識調査

市来 嘉伸 岩浪 崇嗣 柿添 圭成 濱津 隆之 未廣剛敏 米田和恵 田中文啓

杉町 圭蔵

進行·再発非小細胞肺癌に対する Nivolumab 投与症例の検討

$291-297$

児玉 裕美 石田 智恵美 安酸 史子

中堅看護師の新人看護師への教育的役割行動と自己効力感の関係

岩田輝男名部裕介花桐武志田中文啓

瘏痕性気管狭窄に対し気管管状切除術を施行した 1 例

$309-312$

産業医科大学雑誌＼cjkstart第39巻(1-4号) 査読者一覧

産業医科大学雑誌 第39巻(1-4号) 総目次 